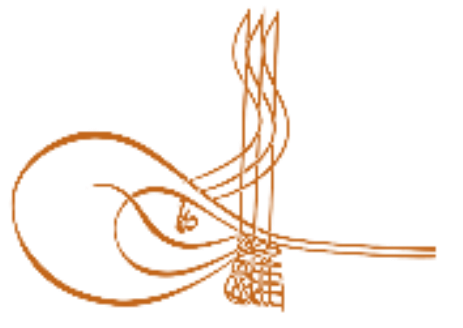

www.turkishstudies.net/turkishstudies
Turkish Studies

eISSN: $1308-2140$

Research Article / Araştırma Makalesi

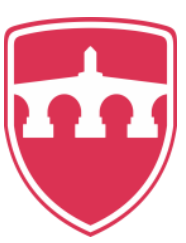

INTERNATIONAL

BALKAN

UNIVERSITY

Sponsored by IBU

\title{
Otel Çalışanlarında Örgütsel Bağlılık ve Etik Liderlik: Ordu İl Merkezinde Bir Araştırma
}

\author{
Organizational Commitment and Ethical Leadership in Hotel Employees: A Research in Ordu \\ Provincial Center
}

\author{
Ayhan Davdeviren* - Mikail Kara** - Hüseyin Özdemir ${ }^{* * *}$
}

\begin{abstract}
The aim of this research is to determine whether hotel employees' organizational commitments and ethical leadership perceptions differ significantly according to socio-demographic characteristics and to determine whether there is a significant relationship between hotel employees' ethical leadership perceptions and organizational commitments. In the research conducted on 634 hotel employees in Ordu provincial center, the questionnaire method was used as a data collection tool. After eliminating the missing, erroneous and unfilled questionnaires from the questionnaires distributed in April and May 2019, 452 valid questionnaires were obtained. The data obtained from the questionnaires were evaluated with the IBM SPSS 22 program. Descriptive statistics, Independent Samples T Test, One-Way ANOVA and correlation analysis were used to analyze the data. As a result of the research, it was revealed that hotel employees' affective commitments showed a statistically significant difference according to age. Also, it was found that hotel employees' continuance commitments showed a statistically significant difference according to the department while their normative commitments showed a statistically significant difference according to gender, marital status, age, department and working time. In addition, it was revealed that hotel employees' ethical leadership perceptions showed a statistically significant difference according to educational status and working time. On the other hand; a statistically significant, positive linear and weak level relationship was found between hotel employees' ethical leadership perceptions and affective, continuance and normative commitments while a statistically significant, positive linear and medium level relation was found between hotel employees' ethical leadership perceptions and organizational commitments.
\end{abstract}

\footnotetext{
* Dr. Öğr. Üyesi, Çankırı Karatekin Üniversitesi Ilgaz Turizm ve Otelcilik Yüksekokulu Asst. Prof. Dr., Cankiri Karatekin University, Ilgaz Tourism and Hotel Management Academy ORCID 0000-0003-0004-8007

ayhandagdeviren@karatekin.edu.tr

*** Dr. Öğr. Üyesi, Çankırı Karatekin Üniversitesi Ilgaz Turizm ve Otelcilik Yüksekokulu

Asst. Prof. Dr., Cankiri Karatekin University, Ilgaz Tourism and Hotel Management Academy

ORCID 0000-0003-1027-3611

mkara@karatekin.edu.tr

**** Dr. Öğr. Üyesi, Çankırı Karatekin Üniversitesi Ilgaz Turizm ve Otelcilik Yüksekokulu

Asst. Prof. Dr., Cankiri Karatekin University, Ilgaz Tourism and Hotel Management Academy

ORCID 0000-0002-9598-6938

huseyinozdemir@karatekin.edu.tr

Cite as/ Atıf: Dağdeviren, A., Kara, M., Özdemir, H. (2020). Otel çalışanlarında örgütsel bağlılık ve etik liderlik: Ordu

il merkezinde bir araştırma, Turkish Studies, 15(1), 117-131. https://dx.doi.org/10.29228/TurkishStudies.40071

Received/Geliş: 19 December/Aralık 2019

Accepted/Kabul: 25 February/Şubat 2020

Checked by plagiarism software

Copyright $(\mathcal{C}$ MDE, Turkey

Published/Yayın: 29 February/Şubat 2020

CC BY-NC 4.0
} 
Structured Abstract: The concept of organizational commitment entered the literature in the 1950s. Different definitions and classifications on organizational commitment have been made in the studies that continue until today (Sürücü and Maşlakç1, 2018). Porter, Steers and Mowday are among those who made the most accepted definition in the literature on organizational commitment. Organizational commitment according to their definition; occurs when individuals identify with the organization and strive for organizational goals and values (Çavuş and Gürdoğan, 2008). Undoubtedly, the studies carried out by Allen and Meyer have an important place in this regard. Allen and Meyer (1990) discussed organizational commitment in three dimensions: affective commitment, continuance commitment and normative commitment. The affective component of organizational commitment, proposed by the model, refers to employees' emotional attachment to, identification with, and involvement in, the organization. The continuance component refers to commitment based on the costs that employees associate with leaving the organization. The normative component refers to employees' feelings of obligation to remain with the organization. The ethical leader can be considered as individuals who are seeking to do the right things, exhibit professional behavior, act in integrity, honesty, fairness and openness (Walumbwa, Avolio, Gardner, Wernsing and Peterson, 2008: 102). The ethical leader is expected to act towards the benefit of the organization, individual, stakeholders and society, and to guide and direct individuals within the framework of organizational goals and objectives (Tuna and Yeşiltaş, 2013: 192). In this respect, it can be said that ethical leadership has direct or indirect effects on many variables of the business (Dedeoğlu, Çelik, İnanır and Altay, 2016: 51). Leadership styles shown by managers in organizations increase the commitment of employees to the goals and values of the organization. Therefore, the sensitivity of leaders to the needs of employees is closely related to organizational commitment (Karahan, 2008: 146).

A limited number of studies (Kim and Brymer, 2011; Çelik, Dedeoğlu, and İnanır, 2015; Dedeoğlu et al. 2016) are found in the tourism literature, where organizational commitment and ethical leadership are examined together. In this research, it is aimed to determine whether hotel employees' organizational commitments and ethical leadership perceptions differ significantly according to demographic characteristics and to determine whether there is a significant relationship between hotel employees' ethical leadership perceptions and organizational commitments, Accordingly, the following hypotheses have been developed:

Hypothesis 1: Hotel employees' organizational commitments (affective, continuance and normative commitment) differ significantly according to socio-demographic characteristics (gender, marital status, age, educational status, department and working time).

Hypothesis 2: Hotel employees' ethical leadership perceptions differ significantly according to sociodemographic characteristics (gender, marital status, age, educational status, department and working time).

Hypothesis 3: There is a significant relationship between hotel employees' ethical leadership perceptions and organizational commitments.

In the research conducted on 634 hotel employees in Ordu provincial center, the questionnaire method was used as a data collection tool. After eliminating the missing, erroneous and unfilled questionnaires from the questionnaires distributed in April and May 2019, 452 valid questionnaires were obtained. The questionnaire form consists of three parts. In the first part of the questionnaire form, Organizational Commitment Scale of Allen and Meyer (1990) consisting of three dimensions was used. In the second part of the questionnaire form, Ethical Leadership Scale, which was developed by Brown, Treviño and Harrison (2005) and whose Turkish validity and reliability study was performed by Tuna, Bircan and Yeşiltaş (2012), was used. In the third part of the questionnaire, there were a total of 6 socio-demographic questions, 3 closedended (gender, marital status and educational status) and 3 open-ended (age, department and working time at the current hotel). The research scales were prepared in five-point Likert type ( $1=$ Strongly Disagree, 2=Disagree, 3=Neither agree nor disagree, 4=Agree, and 5=Strongly Agree). The data obtained from the questionnaires were evaluated with the IBM SPSS 22 program. Descriptive statistics, Independent Samples T Test, One-Way ANOVA and correlation analysis were used to analyze the data. As a result of the research, it was revealed that hotel employees' affective commitments showed a statistically significant difference according to age. Also, it was found that hotel employees' continuance commitments showed a statistically significant difference according to the department while their normative commitments showed a statistically significant difference according to gender, marital status, age, department and working time. In addition, it was revealed that hotel employees' ethical leadership perceptions showed a statistically significant difference according to educational status and working time. On the other hand; a statistically significant, positive linear and weak level relationship was found between hotel employees' ethical leadership perceptions and affective,

Turkish Studies, 15(1) 
continuance and normative commitments while a statistically significant, positive linear and medium level relation was found between hotel employees' ethical leadership perceptions and organizational commitments.

Keywords: Hotel employees, Organizational commitment, Ethical leadership, Ordu.

Öz: Bu araştırmanın amacı, otel çalışanlarının örgütsel bağlılıkları ile etik liderlik algılarının sosyodemografik özelliklere göre anlamlı bir farklılık gösterip göstermediğini belirlemek ve otel çalışanlarının etik liderlik algıları ile örgütsel bağllıkları arasında anlamlı bir ilişki olup olmadığını tespit etmektir. Ordu il merkezinde 634 otel çalışanı üzerinde gerçekleştirilen araştırmada anket yöntemi veri toplama aracı olarak kullanılmıştır. 2019 yılı Nisan ve Mayıs aylarında dağıtılan anketlerden eksik, hatalı ve doldurulmayanların elenmesinden sonra 452 geçerli anket elde edilmiştir. Anketlerden elde edilen veriler, IBM SPSS 22 programı ile değerlendirilmiştir. Verilerin analizinde betimsel istatistikler, Bağımsız Örneklemler T Testi, Tek Yönlü ANOVA ve korelasyon analizinden yararlanılmıştır. Araştırma sonucunda otel çalışanlarının duygusal bağll1ıklarının yaşa göre istatistiki olarak anlamlı bir farklılık gösterdiği ortaya çıkmıştır. Ayrıca, otel çalışanlarının devam bağlılıklarının departmana göre istatistiki olarak anlamlı bir farklılık gösterdiği bulunurken normatif bağlılıklarının cinsiyet, medeni durum, yaş, departman ve çalışma süresine göre istatistiki olarak anlamlı bir farklılık gösterdiği bulunmuştur. Bunun yanında, otel çalışanların etik liderlik algılarının eğitim durumuna ve çalışma süresine göre istatistiki olarak anlamlı bir farklılık gösterdiği ortaya çıkmıştır. Diğer taraftan otel çalışanlarının etik liderlik algıları ile örgütsel bağlılıkları arasında istatistiki olarak anlamlı, pozitif doğrusal ve orta düzeyde bir ilişki bulunurken otel çalışanlarının etik liderlik algıları ile duygusal, devam ve normatif bağllıkları arasında istatistiki olarak anlamlı, pozitif doğrusal ve zayıf düzeyde bir iliş̧i bulunmuştur.

Anahtar Kelimeler: Otel çalışanları, Örgütsel bağlılık, Etik liderlik, Ordu.

\section{Giriş}

Örgütsel bağl1lık kavramı literatüre, 1950’li yıllarda girmiştir. Günümüze kadar devam eden araştırmalarda örgütsel bağlılık konusunda farklı tanım ve sınıflandırmalar yapılmıştır (Sürücü ve Maşlakçı, 2018). Porter, Steers ve Mowday, örgütsel bağlllık ile ilgili literatürde en fazla kabul gören tanımı yapanlar içerisinde yer almaktadır. Onların yaptığı tanıma göre örgütsel bağlılık; bireyler örgütle özdeşleştiklerinde ve örgütsel amaç ve değerler yönünde çaba sarf ettiklerinde ortaya çıkar (Çavuş ve Gürdoğan, 2008). Bu bağlılık, çalışanın işi kabul etmesi ve örgüte kabulünden itibaren yazılı olmayan, ancak varlığ 1 hissedilen psikolojik sözleşmenin kapsamında yer alır. İşe yeni başlayan bir çalışan, zamanla örgütün hedef ve amaçlarını benimseyecek ve işinin gereklerini öğrenecektir. Sonrasında çalışan işletmenin amaçlarını kendi kişisel amaçlarıyla özdeşleştirecek ve bu hedefler doğrultusunda çalışacaktır (Çöllü ve Summak, 2010). Bu noktadan hareketle "örgütsel bağlllık; örgütün amaç ve değerlerine yüksek güven duyarak bu olguların kabul edilmesi, örgüt için çaba harcama ve örgütün bir parçası olarak kalma istekliliği"dir. Literatürde genel kabul gören örgütsel bağl1lık yaklaşımları tutumsal bağlılık, davranışsal bağlılık ve çoklu bağl1lık yaklaşımlarıdır (Yavuz ve Gültekin, 2019). Allen ve Meyer (1990), örgütsel bağl1lı̆̆ duygusal bağl1lık, devam bağgl1lı̆g ve normatif bağl11ı olmak üzere üç boyutlu olarak ele almıştır. Duygusal bağl1lık, çalışanların örgütleri ile özdeşleşmelerinin, örgütün üyesi olmaktan mutluluk duyduklarının ve örgüte güçlü bir biçimde bağlı olduklarının göstergesidir. Duygusal bağlılığı yüksek çalışanların örgüt çıkarlarının gerçekleşmesi için daha fazla çaba göstermesi, onların daha fazla tercih edilmesini sağlamıştır. Devam bağlılığı, çalışanların örgüte devam ettiği süre içerisinde harcadığı, emek, zaman karşılığında elde ettiği ya da gelecekte elde edeceği para, işe ait yetenekler, kıdem, sosyal güvence, emeklilik hakkı gibi kazanımların örgütten ayrılmasıyla kaybedeceği düşüncesiyle oluşan bağlılıktır. Normatif (ahlaki) bağlılık, çalışanların örgütte kalma ile ilgili yükümlülük duygularının bir göstergesidir. Çalışanın işe alım sürecinden itibaren çalışanın eğitimi ve geleceğine yönelik yapılan tüm harcamaların karşılığı olarak çalışanın örgüte bağlı kalma yükümlülüğüdür. Literatürde liderlik tiplerinin örgütsel bağlılığa etkisine yönelik çalışmalara sıklıkla rastlanılmaktadır (Çakınberk ve 
Demirel, 2010; Ceylan, Keskin ve Eren, 2005; Demirağ ve Çelik, 2019; Şentürk, Durak, Y1lmaz, Kaban, Kök ve Baş, 2016; Yavuz, 2009; Yavuz ve Gültekin, 2019). Çalışanlarda örgütsel bağ l11ığın yükselmesine yönelik olarak bireyin sahip olması gereken özelliklerin gelişmesi, liderlik tarzına bağlı olarak ortaya çıkacaktır (Sağır ve Aydın, 2019). Etik lider, doğru şeyleri yapma arayışı içinde olan, profesyonel davranışlar sergileyen, doğruluk, dürüstlük, adalet ve açıklık içinde hareket eden bireyler olarak değerlendirilebilir (Walumbwa vd., 2008: 102). Etik liderin örgüt, birey, paydaşlar ve toplumun faydasına yönelik hareket etmesi ve örgütsel amaçlar ve hedefler çerçevesinde bireyleri yöneltmesi ve rehberlik etmesi beklenir (Tuna ve Yeşiltaş, 2013: 192). Bu yönüyle bakıldığında etik liderliğin işletmenin birçok değişkeni üzerinde doğrudan veya dolaylı olarak etkili olduğu söylenebilir (Dedeoğlu vd., 2016: 51). Örgütlerde yöneticilerin gösterdiği liderlik tarzları ile çalışanların örgütün hedef ve değerlerine olan bağlılığı artmaktadır. Bu nedenle liderlerin çalışanlarının ihtiyaçlarına olan duyarlılı̆g 1 örgütsel bağl1lıkla yakından ilişkilidir (Karahan, 2008: 146).

Turizm literatüründe örgütsel bağl1lık ve etik liderliğin bir arada inceleme konusu yapıldı̆̆ sınırlı sayıda araştırmaya (Kim ve Brymer, 2011; Çelik, vd., 2015; Dedeoğlu vd. 2016) rastlanmaktadır. Örgütsel bağlılık ve etik liderliğin birlikte inceleme konusu yapıldığı bu araştırma, literatüre önemli bir katkı sağlayacaktır.

\section{Amaç}

$\mathrm{Bu}$ araştırmada, otel çalışanlarının örgütsel bağlılıkları ile etik liderlik algılarının sosyodemografik özelliklere göre anlamlı bir farklılık gösterip göstermediğini belirlemek ve otel çalışanlarının etik liderlik algıları ile örgütsel bağlılıkları arasında anlamlı bir ilişki olup olmadığını tespit etmek amaçlanmaktadır. Bu doğrultuda şu hipotezler geliştirilmiştir:

Hipotez 1: Otel çalışanlarının örgütsel bağlılıkları (duygusal bağlılık, devam bağl1lığı ve normatif bağl1lık), sosyodemografik özelliklere (cinsiyet, medeni durum, yaş, eğitim durumu, departman ve çalışma süresi) göre anlamlı bir farklılık gösterir.

Hipotez 2: Otel çalışanlarının etik liderlik algıları, sosyodemografik özelliklere (cinsiyet, medeni durum, yaş, eğitim durumu, departman ve çalışma süresi) göre anlamlı bir farklılık gösterir.

Hipotez 3: Otel çalışanlarının etik liderlik algıları ile örgütsel bağl1lıkları arasında anlamlı bir ilişki vardır.

\section{Yöntem}

\section{Veri Toplama Aracı ve Araştırmanın Ölçekleri}

Araştırmada veri toplama aracı olarak anket yöntemi kullanılmıştır. Anket formu, üç bölümden oluşmuştur. Anket formunun birinci bölümünde, 24 maddeli Allen ve Meyer (1990)'in duygusal bağl1lık, devam bağl1lığı ve normatif bağlılık olmak üzere üç boyuttan oluşan "Örgütsel Bağlllık Ölçeği” kullanılmıştır. Anket formunun ikinci bölümünde, 10 maddeli Brown vd. (2005) tarafından geliştirilen ve Tuna vd. (2012) tarafından Türkçe geçerlilik ve güvenilirlik çalışması yapılan "Etik Liderlik Ölçeği” kullanılmıştır. Anket formunun üçüncü bölümünde; cinsiyet, medeni durum ve eğitim durumu kapalı uçlu; yaş, departman ve mevcut oteldeki çalışma süresi açık uçlu olmak üzere toplam 6 sosyodemografik soru yer almıştır. Katılımcılar ölçek ifadelerini "Kesinlikle Katılmıyorum (1)" ile Kesinlikle Katılıyorum (5) arasında değişen 5'li Likert tipi ölçek üzerinden değerlendirmişlerdir.

\section{Araştırmanın Evreni ve Örneklemi}

Araştırmanın evrenini Ordu il merkezinde faaliyet gösteren otellerin çalışanları oluşturmaktadır. Araştırma, çalışmaya katılmayı kabul eden bir tanesi beş yıldızlı, üç tanesi dört yıldızlı ve dört tanesi üç yıldızlı olmak üzere sekiz farklı otelde görev yapan 634 çalışan üzerinde 
gerçekleştirilmiştir. 2019 yılı Nisan ve Mayıs aylarında dağıtılan anketlerden eksik, hatalı ve doldurulmayanların elenmesinden sonra 452 geçerli anket elde edilmiştir.

\section{Verilerin Analizi}

Araştırma sonucunda elde edilen veriler, IBM SPSS 22 programı ile analiz edilmiştir ve Cronbach Alpha ile ölçeklerin iç tutarlılık güvenilirliği hesaplanmıştır. Ölçeklerin Cronbach Alpha katsayıları örgütsel bağl1lık için ,935, duygusal bağl1lık boyutu için ,892, devam bağl1lığı boyutu için ,887, normatif bağl1lık boyutu için ,895, ve etik liderlik için ,920 olarak hesaplanmıştır. Bu da ölçeğin yüksek derecede güvenilir bir ölçek $(0,80 \leq \alpha<1,00)$ olduğunu göstermektedir (Ural ve Kılıç, 2013: 280; Can, 2013: 343). KMO (Kaiser-Meyer-Olkin) örneklem yeterliliğini ölçmeye yarayan bir testtir ve buradaki yeterlilik sayı değil; ilişkiler anlamındadır. 0,9 ve üzeri mükemmel, 0,7 ve üzeri iyi, $0,5-$ 0,7 arası yeterli, 0,5 'in altı ise yeterli ilişkiyi sağlayacak örneklem ihtiyacını ifade etmektedir (Can, 2013: 277; Çokluk, Şekercioğlu ve Büyüköztürk, 2012: 207; Kalayc1, 2014: 322). Bu çalışmada örneklem yeterliliğini temsil eden KMO oranı ,905 olarak belirlenmiş olup, araştırmada ele alınan örneklem büyüklüğünün mükemmel olduğu sonucuna varılmıştır. Bartlett Küresellik Testi (Bartlett's Test of Sphericity) sonucunda ise anlamlllık değeri $p=0,000<0,05$ olarak belirlenmiştir. Test sonucunun anlamlı olması, veriler arasında ilişki olduğunu ifade etmektedir.

\section{Bulgular}

Tablo 1'e göre araştırmaya katılan otel çalışanlarının \%59,5'i (269 kişi) erkek, \%40,5'i (183 kişi) ise kadındır. Otel çalışanlarının \%48,0'1 (217 kişi) evli iken \%52,0'1 (235 kişi) bekârdır. Otel çalıșanlarının yaş gruplarına göre dağılımına bakıldığında 19-27 yaş arası grubun \%26,8 (121 kiși) ile ilk sırada yer aldığı görülmektedir. Bu grubu sırası ile 30-31 yaş arası grup (\%25,2-114 kişi), 2829 yaş aras1 grup (\%24,1-109 kişi), 32 yaş ve üzeri grup (\%23,9-108 kişi) izlemektedir. Otel çalışanlarının eğitim durumlarına göre dağılımlara bakıldığında lise mezunu grubun \%57,7 (261 kişi) ile en büyük grubu oluşturduğu görülmektedir. Bu grubu sırası ile ön lisans mezunu grup (\%21,5-97 kişi), ilköğretim mezunu grup (\%12,4-56 kişi), lisans ve üzeri mezun grubu (\%8,4-38 kişi) izlemektedir. Otel çalışanlarının çalıştıkları bölümlere göre dağılımlarına bakıldığında kat hizmetleri çalışanlarının \%43,1 (195 kişi) ile ilk sırada yer aldığı görülmektedir. Bu grubu sırası ile mutfak çalışanları (\%32,1-145 kişi), ön büro çalışanları (\%9,7-44 kişi), destek hizmetleri çalışanları (\%7,735 kişi), muhasebe ve insan kaynakları çalışanları (\%7,3-33 kişi) grubu izlemektedir. Otel çalışanlarının çalışma sürelerine göre dağılımlarına bakıldığında 2-3 yıl grubunun \%36,1 (163 kişi) ile ilk sırada yer aldığı görülmektedir. Bu grubu sırası ile 4 yıl ve üzeri çalışan grup (\%35,4-160 kişi), 1 yıl ve altı çalışan grup (\%28,5-129 kişi) izlemektedir. 
Tablo 1: Otel Çalışanlarının Sosyodemografik Özellikleri

\begin{tabular}{|c|c|c|c|}
\hline Sosyodemografik özellik & Grup & $\mathbf{n}$ & $\%$ \\
\hline \multirow{2}{*}{ Cinsiyet } & Erkek & 269 & 59,5 \\
\hline & Kadın & 183 & 40,5 \\
\hline \multirow{2}{*}{ Medeni durum } & Bekâr & 235 & 52,0 \\
\hline & Evli & 217 & 48,0 \\
\hline \multirow{4}{*}{ Yaş } & 19-27 yaş arası & 121 & 26,8 \\
\hline & 28-29 yaş arası & 109 & 24,1 \\
\hline & 30-31 yaş arası & 114 & 25,2 \\
\hline & 32 yaş ve üzeri & 108 & 23,9 \\
\hline \multirow{4}{*}{ Eğitim durumu } & İlköğretim & 56 & 12,4 \\
\hline & Lise & 261 & 57,7 \\
\hline & Ön lisans & 97 & 21,5 \\
\hline & Lisans ve üzeri & 38 & 8,4 \\
\hline \multirow{5}{*}{ Departman } & Mutfak & 145 & 32,1 \\
\hline & Ön büro & 44 & 9,7 \\
\hline & Kat hizmetleri & 195 & 43,1 \\
\hline & Destek hizmetleri & 35 & 7,7 \\
\hline & Muhasebe ve insan kaynakları & 33 & 7,3 \\
\hline \multirow{3}{*}{ Çalışma süresi } & 1 y1l ve alt1 & 129 & 28,5 \\
\hline & 2-3 y1l arası & 163 & 36,1 \\
\hline & 4 yıl ve üzeri & 160 & 35,4 \\
\hline
\end{tabular}

Tablo 2'ye göre araştırmada kullanılan ölçeklerin genel ortalamalarına bakıldığında otel çalışanlarının örgütsel bağlılıklarının ve etik liderlik algılarının 3,41-4,20 aralığında olduğu ve yüksek düzeyde çıktığı görülmektedir. Örgütsel bağlılık boyutlarının puan ortalamaları içinde duygusal bağl1lığın puanı en yüksek iken onu sırası ile devam bağlılığı ve normatif bağlılık takip etmiştir.

Tablo 2: Araştırmada Kullanılan Ölçeklere İlişkin Ortalama ve Standart Sapma Değerleri

\begin{tabular}{ccc}
\hline Ölçek / Boyut & Ortalama & Standart sapma \\
\hline Örgütsel bağlılık & 3,5947 &, 52805 \\
\hline Duygusal bağlllık & 3,7660 &, 64097 \\
\hline Devam băğllı̆̆gl & 3,5780 &, 61627 \\
\hline Normatif bağlllık & 3,4400 &, 62483 \\
\hline Etik liderlik & 3,6719 &, 64875 \\
\hline
\end{tabular}

\section{Hipotezlerin Test Edilmesi}

Hipotez 1: Otel çalışanlarının örgütsel bağl1lıkları (duygusal bağlılık, devam bağlılığı ve normatif bağl1lık), sosyodemografik özelliklere (cinsiyet, medeni durum, yaş, eğitim durumu, departman ve çalışma süresi) göre anlamlı bir farkl11ık gösterir.

Tablo 3’te görüldüğü gibi otel çalışanlarının duygusal bağlılıkları, yaşa göre anlamlı farklılık göstermektedir. Anlamlı farklılığın 32 yaş ve üzeri grup ile 19-27 yaş arası grup ve 28-29 yaş arası grup arasında olduğu görülmektedir. 32 yaş ve üzeri grubun duygusal bağlılı̆̆ının diğer yaş gruplarından daha yüksek olduğu görülmektedir. 19-27 arası yaş grubunun duygusal bağl1lığ diğer gruplara göre daha düşüktür. 
Tablo 3: Otel Çalışanlarının Duygusal Bağlılıklarının Sosyodemografik Özellikleri Göre Anlamlı Farklılık Gösterip Göstermediğine İlişkin Bağımsız Örneklemler T Testi ve Tek Yönlü ANOVA Testi Sonuçları

\begin{tabular}{|c|c|c|c|c|c|c|c|c|}
\hline $\begin{array}{l}\text { Ölçek / } \\
\text { Boyut }\end{array}$ & $\begin{array}{c}\text { Sosyodemografik } \\
\text { ozellik }\end{array}$ & Grup & n & Ortalama & $\begin{array}{l}\text { Standart } \\
\text { sapma }\end{array}$ & $F / t$ & $\mathbf{p}$ & $\begin{array}{l}\text { Tukey } \\
\text { HSD }\end{array}$ \\
\hline \multirow{20}{*}{$\begin{array}{c}\text { Örgütsel } \\
\text { bağlılık } \\
\text { ölçeği } \\
\text { duygusal } \\
\text { bağlılık } \\
\text { boyutu }\end{array}$} & \multirow{2}{*}{ Cinsiyet } & Erkek & 269 & 3,7454 & 63544 & \multirow{2}{*}{,- 828} & \multirow{2}{*}{,408 } & \multirow{2}{*}{-} \\
\hline & & Kadın & 183 & 3,7964 & ,64957 & & & \\
\hline & \multirow{2}{*}{ Medeni durum } & Bekâr & 235 & 3,7351 & 62929 & \multirow{2}{*}{$\begin{array}{c}- \\
1,066\end{array}$} & \multirow{2}{*}{,287 } & \multirow{2}{*}{-} \\
\hline & & Evli & 217 & 3,7995 & ,65318 & & & \\
\hline & \multirow{4}{*}{ Yaş } & $19-27$ yaş arasi $^{a}$ & 121 & 3,6777 & ,66375 & \multirow{4}{*}{2,891} & \multirow{4}{*}{,035 } & \multirow{4}{*}{$\begin{array}{l}\text { d ile a } \\
d \text { ile } b\end{array}$} \\
\hline & & $\begin{array}{c}28-29 \text { yaş } \\
\text { arasi }^{\mathrm{b}}\end{array}$ & 109 & 3,6904 & ,66201 & & & \\
\hline & & $30-31$ yaş arasi ${ }^{c}$ & 114 & 3,8136 & ,59549 & & & \\
\hline & & $\begin{array}{l}32 \text { yaş ve } \\
\text { üzeri }^{\text {d }}\end{array}$ & 108 & 3,8912 & ,62280 & & & \\
\hline & \multirow{4}{*}{ Eğitim durumu } & İlköğretim & 56 & 3,6496 & ,67142 & \multirow{4}{*}{1,761} & \multirow{4}{*}{, 154} & \multirow{4}{*}{-} \\
\hline & & Lise & 261 & 3,7510 & ,64235 & & & \\
\hline & & Ön lisans & 97 & 3,8827 & 59397 & & & \\
\hline & & Lisans ve üzeri & 38 & 3,7434 & ,68153 & & & \\
\hline & \multirow{5}{*}{ Departman } & Mutfak & 145 & 3,7905 & ,52723 & \multirow{5}{*}{, 573} & \multirow{5}{*}{,682 } & \multirow{5}{*}{-} \\
\hline & & Ön büro & 44 & 3,7642 & ,72798 & & & \\
\hline & & Kat hizmetleri & 195 & 3,7737 & 67291 & & & \\
\hline & & $\begin{array}{c}\text { Destek } \\
\text { hizmetleri }\end{array}$ & 35 & 3,7750 & ,71280 & & & \\
\hline & & $\begin{array}{l}\text { Muhasebe ve } \\
\text { insan } \\
\text { kaynakları }\end{array}$ & 33 & 3,6061 & ,71611 & & & \\
\hline & \multirow{3}{*}{ Çalışma süresi } & 1 y1l ve altı & 129 & 3,7665 & 59198 & \multirow{3}{*}{2,077} & \multirow{3}{*}{, 126} & \multirow{3}{*}{-} \\
\hline & & 2-3 y1l arası & 163 & 3,6940 & 67873 & & & \\
\hline & & 4 yll ve üzeri & 160 & 3,8391 & 63497 & & & \\
\hline
\end{tabular}

Tablo 4'te görüldüğü gibi otel çalışanlarının devam bağlılıklarının departmana göre istatistiki olarak anlamlı farklılık göstermektedir. Anlamlı farklılığın "kat hizmetleri çalışanları" ile "mutfak çalışanları" ve "muhasebe ve insan kaynakları çalışanları" arasında olduğu görülmektedir. Devam bağlılığının kat hizmetleri çalışanlarında en yüksek, muhasebe ve insan kaynaklarında ise en düşük olduğu görülmektedir. 
Tablo 4: Otel Çalışanlarının Devam Bağlılıklarının Sosyodemografik Özellikleri Göre Anlamlı Farklılık Gösterip Göstermediğine İlişkin Bağımsız Örneklemler T Testi ve Tek Yönlü ANOVA Testi Sonuçları

\begin{tabular}{|c|c|c|c|c|c|c|c|c|}
\hline $\begin{array}{l}\text { Ölçek / } \\
\text { Boyut }\end{array}$ & $\begin{array}{c}\text { Sosyodemografik } \\
\text { ozzellik }\end{array}$ & Grup & $\mathbf{n}$ & Ortalama & $\begin{array}{l}\text { Standart } \\
\text { sapma }\end{array}$ & $F / t$ & $\mathbf{p}$ & $\begin{array}{l}\text { Tukey } \\
\text { HSD }\end{array}$ \\
\hline \multirow{20}{*}{$\begin{array}{c}\text { Örgütsel } \\
\text { bağlılık } \\
\text { ölçeği } \\
\text { devam } \\
\text { bağlıı̆ı̆ı } \\
\text { boyutu }\end{array}$} & \multirow{2}{*}{ Cinsiyet } & Erkek & 269 & 3,5455 &, 60424 & \multirow{2}{*}{$\begin{array}{l}- \\
1,347\end{array}$} & \multirow{2}{*}{, 179} & \multirow{2}{*}{-} \\
\hline & & Kadın & 183 & 3,6257 & ,63217 & & & \\
\hline & \multirow{2}{*}{ Medeni durum } & Bekâr & 235 & 3,5516 & ,62152 & \multirow{2}{*}{,- 948} & \multirow{2}{*}{,344 } & \multirow{2}{*}{-} \\
\hline & & Evli & 217 & 3,6066 & ,61067 & & & \\
\hline & \multirow{4}{*}{ Yaş } & $19-27$ yaş arası & 121 & 3,5496 & ,63420 & \multirow{4}{*}{,968 } & \multirow{4}{*}{,408 } & \multirow{4}{*}{-} \\
\hline & & 28-29 yaş arası & 109 & 3,5126 & ,61987 & & & \\
\hline & & $30-31$ yaş arası & 114 & 3,6129 & ,58037 & & & \\
\hline & & 32 yaş ve üzeri & 108 & 3,6389 & 62915 & & & \\
\hline & \multirow{4}{*}{ Eğitim durumu } & İlköğretim & 56 & 3,7165 & ,61768 & \multirow{4}{*}{1,937} & \multirow{4}{*}{, 123} & \multirow{4}{*}{ - } \\
\hline & & Lise & 261 & 3,5637 & ,64325 & & & \\
\hline & & Ön lisans & 97 & 3,6005 & ,54744 & & & \\
\hline & & Lisans ve üzeri & 38 & 3,4145 & ,56361 & & & \\
\hline & \multirow{5}{*}{ Departman } & Mutfak $^{\mathrm{a}}$ & 145 & 3,4931 & ,51807 & \multirow{5}{*}{2,702} & \multirow{5}{*}{, 030} & \multirow{5}{*}{$\begin{array}{l}\text { c ile a } \\
\text { c ile e }\end{array}$} \\
\hline & & Ön büro ${ }^{b}$ & 44 & 3,5568 & ,77077 & & & \\
\hline & & Kat hizmetleric $^{\mathrm{c}}$ & 195 & 3,6756 & ,63364 & & & \\
\hline & & $\begin{array}{c}\text { Destek } \\
\text { hizmetleri }^{\mathrm{d}}\end{array}$ & 35 & 3,5857 & ,63287 & & & \\
\hline & & $\begin{array}{c}\text { Muhasebe ve } \\
\text { insan kaynaklari }\end{array}$ & 33 & 3,3939 & 60039 & & & \\
\hline & \multirow{3}{*}{ Çalışma süresi } & 1 y1l ve altı & 129 & 3,5853 & 60937 & \multirow{3}{*}{, 808} & \multirow{3}{*}{, 446} & \multirow{3}{*}{-} \\
\hline & & $2-3$ y1l aras1 & 163 & 3,5322 & ,66327 & & & \\
\hline & & 4 yll ve üzeri & 160 & 3,6188 & ,57116 & & & \\
\hline
\end{tabular}

Tablo 5’te görüldüğü gibi otel çalışanlarının normatif bağlılıkları; cinsiyet, medeni durum, yaş, departman ve çalışma süresine göre istatistiki olarak anlamlı bir farklılık göstermektedir. Anlamlı farklılığın bulunduğu sosyodemografik özelliklerde kadınların normatif bağlılığının erkeklerden, evli olan otel çalışanların normatif bağlılığının bekâr otel çalışanlarından daha yüksek olduğu görülmektedir. Otel çalışanlarının yaş gruplarına bakıldığında anlamlı farklılığın 32 yaş ve üzeri grup ile 19-27 yaş arası grup ve 28-29 yaş arası grup arasında olduğu görülmektedir. Otel çalışanlarının normatif bağl1lıklarının 32 yaş ve üzeri grupta diğer yaş gruplarından daha yüksek olduğu görülmektedir. Otel çalışanlarının normatif bağlılığının departmana göre kat hizmetleri çalışanlarında en yüksek olduğu, anlamlı farklılığın kat hizmetleri çalışanları ile mutfak çalışanları arasında olduğu görülmektedir. Otel çalışanlarının otellerde çalışma sürelerine bakıldığında anlamlı farklılığın 4 yıl ve üzeri çalışanlar ile 2-3 yıl arası çalışanlar arasında olduğu görülmektedir. 4 yıl ve üzeri çalışanların normatif bağlılıklarının diğer çalışma sürelerine sahip gruplardan daha yüksek olduğu görülmektedir. 
Tablo 5: Otel Çalışanlarının Normatif Bağlılıklarının Sosyodemografik Özelliklere Göre Anlamlı Farklılık Gösterip Göstermediğine İlişkin Bağımsız Örneklemler T Testi ve Tek Yönlü ANOVA Testi Sonuçları

\begin{tabular}{|c|c|c|c|c|c|c|c|c|}
\hline $\begin{array}{l}\text { Ölçek / } \\
\text { Boyut }\end{array}$ & $\begin{array}{c}\text { Sosyodemografik } \\
\text { ozzellik }\end{array}$ & Grup & $\mathbf{n}$ & Ortalama & $\begin{array}{c}\text { Standart } \\
\text { sapma }\end{array}$ & $F / t$ & $\mathbf{p}$ & $\begin{array}{c}\text { Tukey } \\
\text { HSD }\end{array}$ \\
\hline \multirow{20}{*}{$\begin{array}{c}\text { Örgütsel } \\
\text { bağlılık } \\
\text { ölçeği } \\
\text { normatif } \\
\text { bağlılık } \\
\text { boyutu }\end{array}$} & \multirow{2}{*}{ Cinsiyet } & Erkek & 269 & 3,3722 & ,60161 & \multirow{2}{*}{$2, \overline{7}+$} & \multirow{2}{*}{, 006} & \multirow{2}{*}{-} \\
\hline & & Kadın & 183 & 3,5396 & 64631 & & & \\
\hline & \multirow{2}{*}{ Medeni durum } & Bekâr & 235 & 3,3809 & ,59425 & \multirow{2}{*}{2,094} & \multirow{2}{*}{,037 } & \multirow{2}{*}{-} \\
\hline & & Evli & 217 & 3,5040 & ,65167 & & & \\
\hline & \multirow{4}{*}{ Yaş } & $19-27$ yaş arasi $^{\text {a }}$ & 121 & 3,3533 & ,60846 & \multirow{4}{*}{3,946} & \multirow{4}{*}{, 008} & \multirow{4}{*}{$\begin{array}{l}\text { d ile a } \\
\text { d ile b }\end{array}$} \\
\hline & & $28-29$ yaş arası ${ }^{b}$ & 109 & 3,3498 & ,59991 & & & \\
\hline & & $30-31$ yaş arasi $^{\mathrm{c}}$ & 114 & 3,4704 & ,62783 & & & \\
\hline & & 32 yaş ve üzerid ${ }^{d}$ & 108 & 3,5961 & ,63912 & & & \\
\hline & \multirow{4}{*}{ Eğitim durumu } & İlköğretim & 56 & 3,4487 & ,70702 & \multirow{4}{*}{,910 } & \multirow{4}{*}{,436 } & \multirow{4}{*}{-} \\
\hline & & Lise & 261 & 3,4104 & ,62774 & & & \\
\hline & & Ön lisans & 97 & 3,4575 & ,57929 & & & \\
\hline & & Lisans ve üzeri & 38 & 3,5855 & ,58925 & & & \\
\hline & \multirow{5}{*}{ Departman } & Mutfak $^{\mathrm{a}}$ & 145 & 3,3233 &, 52655 & \multirow{5}{*}{2,498} & \multirow{5}{*}{, 042} & \multirow{5}{*}{ c ile a } \\
\hline & & Ön bürob & 44 & 3,5170 & ,73066 & & & \\
\hline & & Kat hizmetleric & 195 & 3,5186 & ,66633 & & & \\
\hline & & $\begin{array}{c}\text { Destek } \\
\text { hizmetleri }^{\mathrm{d}}\end{array}$ & 35 & 3,3429 & ,59590 & & & \\
\hline & & $\begin{array}{c}\text { Muhasebe ve } \\
\text { insan kaynakları }\end{array}$ & 33 & 3,4886 & ,58992 & & & \\
\hline & \multirow{3}{*}{ Çalışma süresi } & $1 \mathrm{y} 1 \mathrm{lve}$ alt1 $^{\mathrm{a}}$ & 129 & 3,4428 & ,57047 & \multirow{3}{*}{2,877} & \multirow{3}{*}{, 057} & \multirow{3}{*}{ c ile b } \\
\hline & & $2-3$ y1l arasi $^{b}$ & 163 & 3,3566 & ,64493 & & & \\
\hline & & 4 yıl ve üzeric & 160 & 3,5227 & ,63844 & & & \\
\hline
\end{tabular}

Hipotez 2: Otel çalışanlarının etik liderlik algıları, sosyodemografik özelliklere (cinsiyet, medeni durum, yaş, eğitim durumu, departman ve çalışma süresi) göre anlamlı bir farklılık gösterir.

Tablo 6'da görüldüğ̈̈ gibi otel çalışanlarının etik liderlik algıları eğitim durumuna ve oteldeki çalışma süresine göre istatistiki olarak anlamlı bir farklılık göstermektedir. Eğitim durumuna göre anlamlı farklılık, lisans ve üzeri grup ile ilköğretim mezunu grup arasındadır. Eğitim durumuna göre etik liderlik algısı en yüksek grubu, lisans ve üzeri mezun çalışanlar oluştururken en düşük grubu, ilköğretim mezunu çalışanlar oluşturmaktadır. Otel çalışanlarının mevcut oteldeki çalışma sürelerine bakıldığında anlamlı farklılığın 4 yıl ve üzeri çalışanlar ile 2-3 yıl arası çalışan grup arasında olduğu görülmektedir. 4 yıl ve üzeri çalışan grubun etik liderlik algısının diğer gruplardan daha yüksek olduğu görülmektedir. 
Tablo 6: Otel Çalışanlarının Etik Liderlik Algılarının Sosyodemografik Özellikleri Göre Anlamlı Farklılık Gösterip Göstermediğine İlişkin Bağımsız Örneklemler T Testi ve Tek Yönlü ANOVA Testi Sonuçları

\begin{tabular}{|c|c|c|c|c|c|c|c|c|}
\hline Ölçek & $\begin{array}{c}\text { Sosyodemografik } \\
\text { ozzellik }\end{array}$ & Grup & $\mathbf{n}$ & Ortalama & $\begin{array}{c}\text { Standart } \\
\text { sapma }\end{array}$ & $F / t$ & $\mathbf{p}$ & $\begin{array}{l}\text { Tukey } \\
\text { HSD }\end{array}$ \\
\hline \multirow{20}{*}{$\begin{array}{c}\text { Etik } \\
\text { liderlik } \\
\text { ölçeği }\end{array}$} & \multirow{2}{*}{ Cinsiyet } & Erkek & 269 & 3,6305 &, 64603 & \multirow{2}{*}{$\begin{array}{c}- \\
1,647\end{array}$} & \multirow{2}{*}{, 100} & \multirow{2}{*}{ - } \\
\hline & & Kadın & 183 & 3,7328 & ,64970 & & & \\
\hline & \multirow{2}{*}{ Medeni durum } & Bekâr & 235 & 3,6421 & ,64329 & \multirow{2}{*}{$\begin{array}{c}- \\
1,015\end{array}$} & \multirow{2}{*}{,311 } & \multirow[b]{2}{*}{-} \\
\hline & & Evli & 217 & 3,7041 & ,65456 & & & \\
\hline & \multirow{4}{*}{ Yaş } & 19-27 yaş arası & 121 & 3,6372 & ,62131 & \multirow{4}{*}{2,351} & \multirow{4}{*}{,072 } & \multirow{4}{*}{ - } \\
\hline & & $28-29$ yaş arası & 109 & 3,5706 & 69991 & & & \\
\hline & & $30-31$ yaş arası & 114 & 3,6886 & ,65213 & & & \\
\hline & & 32 yaş ve üzeri & 108 & 3,7954 & 60826 & & & \\
\hline & \multirow{4}{*}{ Eğitim durumu } & İlköğretim ${ }^{\mathrm{a}}$ & 56 & 3,4875 & ,66004 & \multirow{4}{*}{3,664} & \multirow{4}{*}{,012 } & \multirow{4}{*}{ d ile a } \\
\hline & & Lise $^{\mathrm{b}}$ & 261 & 3,6517 & 63389 & & & \\
\hline & & Ön lisans ${ }^{\mathrm{c}}$ & 97 & 3,7412 & 64157 & & & \\
\hline & & Lisans ve üzeri $^{\mathrm{d}}$ & 38 & 3,9053 & ,68416 & & & \\
\hline & \multirow{5}{*}{ Departman } & Mutfak & 145 & 3,6269 & 61984 & \multirow{5}{*}{,428 } & \multirow{5}{*}{,788 } & \\
\hline & & Ön büro & 44 & 3,7227 & ,77934 & & & \\
\hline & & Kat hizmetleri & 195 & 3,6718 & ,62332 & & & \\
\hline & & Destek hizmetleri & 35 & 3,7600 & ,64407 & & & \\
\hline & & $\begin{array}{c}\text { Muhasebe ve insan } \\
\text { kaynakları }\end{array}$ & 33 & 3,7091 & ,75348 & & & \\
\hline & \multirow{3}{*}{ Çalışma süresi } & 1 y1l ve alt1 ${ }^{\mathrm{a}}$ & 129 & 3,7147 & ,64881 & \multirow{3}{*}{3,584} & \multirow{3}{*}{,029 } & \multirow{3}{*}{ c ile b } \\
\hline & & 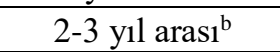 & 163 & 3,5650 & ,67883 & & & \\
\hline & & 4 yll ve üzeri ${ }^{c}$ & 160 & 3,7462 & ,60552 & & & \\
\hline
\end{tabular}

Hipotez 3: Otel çalışanlarının etik liderlik algıları ile örgütsel bağlılıkları arasında anlamlı bir ilişki vardır.

Tablo 7'de görüldüğü gibi otel çalışanlarının etik liderlik algıları ile örgütsel bağlılıkları arasında istatistiki olarak anlamlı $(\mathrm{p}=0,00 ; \mathrm{p}<0,01)$, pozitif doğrusal ve orta düzeyde bir ilişki $(\mathrm{r}=, 506)$, etik liderlik algıları ile duygusal bağlılıkları arasında istatistiki olarak anlamlı $(\mathrm{p}=0,00$; $\mathrm{p}<0,01)$, pozitif doğrusal ve zayıf düzeyde bir ilişki $(\mathrm{r}=, 492)$, etik liderlik algıları ile devam bağlılıkları arasında istatistiki olarak anlamlı $(\mathrm{p}=0,00 ; \mathrm{p}<0,01)$, pozitif doğrusal ve zayıf düzeyde bir ilişki ( $\mathrm{r}=, 340)$, etik liderlik algıları ile normatif bağlılıkları arasında istatistiki olarak anlamlı $(\mathrm{p}=0,00$; $\mathrm{p}<0,01)$, pozitif doğrusal ve zayıf düzeyde bir ilişki $(\mathrm{r}=, 444)$ vardır.

Tablo 7: Etik Liderlik ile Örgütsel Bağlılık Arasındaki İlişki

\begin{tabular}{|c|c|c|c|c|c|}
\hline \multicolumn{2}{|c|}{ Pearson korelasyon matrisi } & $\begin{array}{l}\text { Örgütsel } \\
\text { bağlılık }\end{array}$ & $\begin{array}{c}\text { Duygusal } \\
\text { bağlılık }\end{array}$ & $\begin{array}{l}\text { Devam } \\
\text { bağlılığ }\end{array}$ & $\begin{array}{l}\text { Normatif } \\
\text { bağlılık }\end{array}$ \\
\hline \multirow{3}{*}{$\begin{array}{c}\text { Etik } \\
\text { liderlik }\end{array}$} & Pearson &, $506 * *$ &, $\mathbf{4 9 2}^{* *}$ &, $\mathbf{3 4 0}^{* * *}$ &, $\mathbf{4 4 4} 4^{* *}$ \\
\hline & $\begin{array}{l}\text { correlation } \\
\text { Sig (2-tailed) }\end{array}$ &, 000 &, 000 &, 000 &, 000 \\
\hline & N & 452 & 452 & 452 & 452 \\
\hline
\end{tabular}

Tablo 8'de hipotez sonuçları verilmiștir. Otel çalışanlarının duygusal bağlılıkları yaşa göre, devam bağl1lıkları departmana göre, normatif bağl1lıkları cinsiyet, medeni durum, yaş, departman ve oteldeki çalışma süresine göre istatistiki olarak anlamlı bir farklılık gösterdiği için Hipotez 1 kısmen kabul edilmiştir. Ayrıca, otel çalışanların etik liderlik algıları eğitim durumuna ve çalışma süresine göre istatistiki olarak anlamlı bir farklılık gösterdiği için Hipotez 2 de kısmen kabul edilmiştir. Diğer taraftan otel çalışanlarının etik liderlik algıları ile örgütsel bağlılıkları arasında istatistiki olarak anlamlı, pozitif doğrusal ve orta düzeyde bir ilişki bulunurken otel çalışanlarının etik liderlik algıları 
ile duygusal, devam ve normatif bağl1lıkları arasında istatistiki olarak anlamlı, pozitif doğrusal ve zayıf düzeyde bir ilişki bulunmuştur. Dolayısıyla Hipotez 3 kabul edilmiştir.

Tablo 8: Hipotez Sonuçları

\begin{tabular}{cc}
\hline Hipotez & Sonuç \\
\hline Hipotez 1 & Klsmen kabul edildi. \\
\hline Hipotez 2 & Klsmen kabul edildi. \\
\hline Hipotez 3 & Kabul edildi. \\
\hline
\end{tabular}

\section{Sonuç}

Araştırma sonuçlarına göre, kadın otel çalışanlarının örgütsel bağl1lıkları erkek çalışanlardan daha yüksektir. Otel çalışanlarının duygusal bağlılıkları, devam ve normatif bağlılıklarından daha yüksektir. Evli olan otel çalışanlarının duygusal bağlılıkları, devam bağlılıkları ve normatif bağl1lıkları, bekâr otel çalışanlarından daha yüksektir. 32 yaş ve üzeri otel çalışanlarının duygusal bağlılıkları, devam bağl1lıkları ve normatif bağl1lıkları diğer yaş gruplarından daha yüksektir. 4 yıl ve üzeri otel çalışanlarının örgütsel bağlılıkları, duygusal bağlılıkları, devam bağlılıkları ve normatif bağlılıkları diğer çalıșma sürelerine sahip gruplardan daha yüksektir. Otel çalıșanlarının etik liderlik algılarına bakıldığında, kadın çalışanların erkek çalışanlardan, evli çalışanların bekâr çalışanlardan, 32 yaş ve üzeri çalışanların diğer yaş gruplarından, lisans ve üzeri mezunların diğer eğitim durumlarından, destek hizmetleri çalışanlarının diğer departmanlarda çalışanlardan ve 4 yıl ve üzeri çalışma süresine sahip otel çalışanlarının diğer çalışma sürelerine sahip otel çalışanlarından daha yüksek etik liderlik algısına sahip oldukları görülmüştür.

Özdemir ve Yaylı (2014) araştırmalarında, güvenlik personelinin duygusal bağl1lığının devam ve normatif bağl1lıktan daha yüksek olduğunu; Mumcu ve Alici (2016), sosyal yardımlaşma ve dayanışma vakfı personelinin devam bağl1lığının duygusal ve normatif bağlılıklarından daha yüksek olduğunu; Özdemir, Dağdeviren, Göker ve Özdemir (2017), otel çalışanlarının devam bağlılığının duygusal ve normatif bağlllıklarından daha yüksek olduğunu; Koc (2018), akademisyenlerin devam bağlılığının duygusal ve normatif bağlılıklarından daha yüksek olduğunu tespit etmiştir.

Tavas ve Öztürk (2016), Türk Polis Teşkilatında çalışan kadın personelin örgütsel bağlılıklarının erkek personelden daha yüksek olduğunu; Demirbolat, İhtiyaroğlu ve Köse (2017) yürüttükleri araştırmanın sonucunda, kadın öğretmenlerin örgütsel bağl1lıklarının erkek öğretmenlerden daha yüksek olduğunu; Parasız, Koç, Ilgar ve Şahin (2017) ise Beden Eğitimi ve Spor Anabilim Dalı'nda görev yapan erkek akademisyenlerin örgütsel bağlılıklarının kadın akademisyenlerden daha yüksek olduğunu saptamışlardır.

Yalçın ve İplik (2005), otel çalışanlarının duygusal, devam ve normatif bağlılıklarının, cinsiyet, medeni durum, bulundukları otel ve pozisyondaki toplam çalışma sürelerine göre farkl11ık göstermediğini; ancak devam bağlılıklarının yaş ve eğitim düzeylerine; duygusal bağlılıklarının ise yaş, eğitim ve gelir düzeylerine göre anlamlı bir farklılık gösterdiğini tespit etmiştir. Ağca ve Ertan (2008), otel çalışanlarının en yüksek örgütsel bağlılığının duygusal bağl1lıkta olduğunu, onu sirasıyla devam ve normatif bağl1lığın takip ettiğini, otel çalışanlarının duygusal bağlılı̆̆ın yaş, çalışılan bölüm, unvan, çalışma süresi, meslek süresi değişkenlerine, devamlılık bağlılığının yaş, medeni durum, çalışılan bölüm, çalışma süresi değişkenlerine, normatif bağl1lı̆̆n ise yaş, eğitim, medeni durum ve unvan değişkenlerine bağlı olarak değiştiğini saptamıştır. Çolakoğlu, Ayyıldız ve Cengiz (2009), otel çalışanların eğitim durumu, departmanı, deneyim süreleri ve gelirlerine göre duygusal, devam ve normatif bağglılıklarında önemli farklılık olduğunu bulmuşlardır. Özdemir (2019), otel çalışanlarının en yüksek örgütsel bağlılığının devam bağlılı̆̆ında olduğunu, en düşük örgütsel bağ lılığının normatif bağll1ıkta olduğunu tespit etmiştir. Çalışanların cinsiyetlerine ve medeni durumlarına göre örgütsel bağl1lıklarının anlamlı bir değişiklik göstermediğini, duygusal ve devam 
bağlılıklarının eğitim düzeylerine göre anlamlı bir değişiklik gösterdiğini, yaş ve kıdem ile örgütsel bağl1lık arasında anlamlı ilişki bulunmadığını tespit etmiştir.

Kim ve Brymer (2011), üst yönetimin etik liderliğinin otel müdürlerinin duygusal bağl1lıkları ile pozitif düzeyde ilişkili olduğunu tespit etmiştir. Esmer (2013) Ziraat Bankası çalışanları üzerinde yürüttüğü araştırmanın sonucunda, etik liderlik ile örgütsel bağlılık arasında bir ilişkinin olduğu tespit etmiştir. Ayrıca banka çalışanlarının örgütsel bağlılık eğilimleri ve etik liderlik eğilimleri ile yaş ve gelir açısından ters, eğitim düzeyi ile de aynı yönlü bir ilişkinin olduğunu tespit etmiştir. Uğurlu, Sincar ve Çınar (2013) araştırmalarında, okul yöneticilerinin etik liderlik davranışlarının öğretmenlerin örgütsel bağlılıklarına ilişkin duygusal bağlılığı, devam bağlılığını ve normatif bağlılı̆̆ ayrı ayrı açıklamada anlamlı bir etkiye sahip olduğunu saptamışlardır. Madenoğlu, Uysal, Sarıer ve Banoğlu (2014) araştırmalarında, okul müdürlerinin etik liderlik davranışlarının öğretmenlerin örgütsel bağlılık düzeyinin açıklanmasına katkı sağladığı sonucuna ulaşmıştır. Çelik vd. (2015), otel çalışanları üzerinde yaptığı araştırma sonucunda etik liderliğin örgütsel bağlılık üzerinde olumlu etkisi olduğunu saptamışlardır. Dedeoğlu vd. (2016) otel çalışanları üzerinde yaptığı araştırma sonucunda, etik liderliğin örgütsel bağlılık üzerindeki etkisinde hem cinsiyet hem de çalışma süresinin farklılaştırıcı rolü olduğunu-erkeklere göre kadınların örgütsel bağlılıklarında etik liderliğin daha önemli bir faktör olduğunu, işletmede bir yıl ve daha az süre çalışanların bir yıldan daha fazla süre çalışanlara oranla etik liderliğin örgüte bağlılıkları açısından daha belirleyici olduğunu-tespit etmişlerdir.

$\mathrm{Bu}$ araştırma sonucunda otel çalışanlarının etik liderlik algıları ile örgütsel bağl1lıkları arasında istatistiki olarak anlamlı, pozitif doğrusal ve orta düzeyde bir ilişki tespit edilirken otel çalışanların etik liderlik algıları ile duygusal, devam ve normatif bağlılıkları arasında istatistiki olarak anlamlı, pozitif doğrusal ve zayıf düzeyde bir ilişki tespit edilmiştir.

Yöneticilerin etik davranışlar sergilemesi, çalışanların işletmeye karşı olumlu düşüncelere sahip olmalarını sağlayacak, onların örgütlerine olan bağlılıklarını artıracaktır. Diğer taraftan yöneticilerin etik ilkelerin yön verdiği örgütsel iklimi oluşturmaları; çalışan başarısına, müşteri memnuniyetine ve işletme imajına olumlu yansıyacaktır.

Bu araştırma, bazı sınırlılıklara sahiptir. Birincisi bu araştırma, Ordu il merkezinde bulunan otellerin çalışanları üzerinde gerçekleştirilmiştir. Benzer bir araştırma, farklı sahalarda, farklı işletme türlerinde yürütülebilir. İkincisi, bu araştırmada nicel araştırma yönteminden yararlanılmıştır. Daha sonra yürütülecek araştırmalarda nitel ve karma yöntemler bir arada kullanılabilir. Üçüncüsü, bu araştırma verilerinin analizinde betimsel istatistikler, Bağımsız Örneklemler T Testi, Tek Yönlü ANOVA ve korelasyon analizinden yararlanılmıştır. Daha sonra yürütülecek araştırmalarda farklı istatistiki analizlerden yararlanılabilir.

\section{Kaynakça}

Ağca, V. ve Ertan, H. (2008). Çalışanların örgütsel bağlılıklarının demografik özelliklerine bağlı olarak değişmesi: Antalya'da beş yıldızlı otellerde bir inceleme. Dumlupınar Üniversitesi Sosyal Bilimler Dergisi, (22).

Allen, N.J. ve Meyer, J.P. (1990). The measurement and antecedents of affective, continuance and normative commitment of the organization. Journal of Occupational Psychology, 1990(639), 1-18. https://doi.org/10.1111/j.2044-8325.1990.tb00506.x.

Brown, M. E., Treviño, L. K. ve Harrison, D. A. (2005). Ethical leadership: A social learning perspective for construct development and testing. Organizational Behavior and Human Decision Processes, 97(2),117-134. https://doi.org/10.1016/j.obhdp.2005.03.002.

Can, A. (2013). SPSS ile bilimsel araştırma sürecinde nicel veri analizi. Ankara: Pegem Akademi. 
Ceylan, A., Keskin, H. ve Eren, Ş. (2005). Dönüşümcü ve etkileşimci liderlik ile örgütsel bağl1l1k arasındaki ilişkilere yönelik bir araştırma. Istanbul Management Journal, 16(51), 32-42.

Çakınberk, A. ve Demirel, E. T. (2010). Örgütsel bağl1lı̆̆ın belirleyicisi olarak liderlik: sağlık çalışanları örneği. Selçuk Üniversitesi Sosyal Bilimler Enstitüsü Dergisi, 24, 103-119.

Çavuş, Ş. ve Gürdoğan, A. (2008). Örgüt kültürü ve örgütsel bağlılık ilişkisi: Beş yıldızlı bir otel işletmesinde araştırma. Gazi Üniversitesi Ticaret ve Turizm Eğitim Fakültesi Dergisi, (1), 18-34.

Çelik, S., Dedeoğlu, B. B. ve İnanır, A. (2015). Relationship between ethical leadership, organizational commitment and job satisfaction at hotel organizations. Ege Akademik Bakış Dergisi, 15(1), 53-64.

Çokluk, Ö., Şekercioğlu, G. ve Büyüköztürk, Ş. (2012). Sosyal bilimler için çok değişkenli istatistik SPSS ve LISREL uygulamalarl, 2. Bask1, Ankara: Pegem Akademi.

Çolakoğlu, Ü., Ayyıldız, T. ve Cengiz, S. (2009). Çalışanların demografik özelliklerine göre örgütsel bağlılık boyutlarında algılama farklılıkları: Kuşadası'ndaki beş yıldızlı konaklama işletmeleri örneği. Anatolia: Turizm Araştırmaları Dergisi, 20(1), 77-89.

Çöllü, E. F., ve Summak, M. E. (2010). Örgütsel iletişimin örgütsel bağl1lı̆ga etkisi: Konya'da bulunan mali müşavir çalışanları üzerine bir araştırma. Selçuk Üniversitesi Sosyal Bilimler Meslek Yüksek Okulu Dergisi, 13(1-2), 273-288.

Dedeoğlu, B., Çelik, S., İnanır, A. ve Altay, H. (2016). Etik liderlik, örgütsel bağl1lık ve iş tatmini arasındaki ilişkide: Cinsiyet ve çalışma süresinin farklılaştırıcı (moderate) rolü. Yönetim ve Ekonomi Araştırmaları Dergisi, 14(4), 45-70. https://doi.org/10.11611/yead.282215.

Demirağ, B. ve Çelik, M. (2019). Lider davranış özelliklerinin örgütsel bağl1lık üzerindeki etkisi. Mehmet Akif Ersoy Üniversitesi Sosyal Bilimler Enstitüsü Dergisi, 11(27), 1-21. https://doi.org/10.20875/makusobed.401700.

Demirbolat, A.O., İhtiyaroğlu, N. ve Köse, E. K. (2017). An investigation of the relationship between the affective, normative, and continuance commitment of teachers and levels of effectiveness. European Journal of Education Studies, 3(7), 38-56. https://doi.org/10.5281/zenodo.80599.

Esmer, Y. (2013). Banka işletmelerinde etik liderlik ve örgütsel bağlılık ilişkisi: Ziraat Bankası örneği. Aksaray Üniversitesi İ̈BF Dergisi, 5(2), 41-61.

Kalayc1, Ş. (2014). "Faktör analizi.” SPSS uygulamalı çok değişkenli istatistik teknikleri. (Ed.) Şeref Kalayc1. Ankara: Asil Yayın Dağıtım. 321-331.

Karahan, A. (2008). Hastanelerde liderlik ve örgütsel bağlılık arasındaki ilişkinin incelenmesi. Sosyal Bilimler Dergisi, 10 (1), 145-162. http://dx.doi.org/10.11611/JMER299.

Kim, W. G. ve Brymer, R. A. (2011). The effects of ethical leadership on manager job satisfaction, commitment, behavioral outcomes, and firm performance. International Journal of Hospitality Management, 30(4), 1020-1026. https://doi.org/10.1016/j.ijhm.2011.03.008.

Koc, M. (2018). Research on correlations between academicians' levels of organisational commitment and their intention to quit their job: A comparison of state and foundation universities. Journal of Education and Learning, 7(1), 163-173. https://doi.org/10.5539/jel.v7n1p163. 
Madenoğlu, C., Uysal, Ş., Sarıer, Y. ve Banoğlu, K. (2014). Okul müdürlerinin etik liderlik davranışları ile öğretmenlerin iş doyumlarının örgütsel bağl1lıla ilişkisi. Kuram ve Uygulamada Ĕ̈itim Yönetimi, 20(1), 47-69. https://doi.org/10.14527/kuey.2014.003

Mumcu, A. ve Alici, İ. (2016). Örgütsel bağlılığın alt boyutları ile işten ayrılma niyeti arasındaki ilişki: Sosyal yardımlaşma ve dayanışma vakfı personeli üzerine bir araştırma. Örgütsel Davranış Araştırmaları Dergisi, 1(1), 35-52.

Özdemir, H. ve Yaylı, A. (2014). Çalışanın örgütsel bağlılığını, performansı ve işte ayrılma niyeti arasındaki ilişkinin belirlenmesine yönelik bir araştırma. Journal of Recreation and Tourism Research, 1(1), 48-58.

Özdemir, H., Dağdeviren, A., Göker, G.ve Özdemir, S. N. (2017). Otel çalışanlarının iş tatmini ve örgütsel bağl1lık düzeyleri üzerine bir araştırma. Güncel Turizm Araştırmaları Dergisi, 1(2), 114-123.

Özdemir, H. Ö. (2019). Konaklama işletmelerinde çalışan personelin örgütsel bağlılıklarının çeşitli açlardan incelenmesi. Ahi Evran Üniversitesi Sosyal Bilimler Enstitüsü Dergisi, 5(2), 237250.

Parasız, Ö., Koç, M., Ilgar, E. ve Şahin, M. Y., (2017). Relationship between organizational commitment and turnover intentions of academics. Journal of Human Sciences, 14(4), 40654076. https://doi.org/10.14687/jhs.v14i4.5076.

Sağır, M. ve Aydın, A. U. (2019). Otantik liderlik, örgütsel bağlılık ve psikolojik sermaye arasındaki ilişki: Tekstil sektöründe bir uygulama. Selçuk Üniversitesi Sosyal Bilimler Meslek Yüksekokulu Dergisi, 22(2), 800-812. https://doi.org/10.29249/selcuksbmyd.590737.

Sürücü, L. ve Maşlakçı, A. (2018). Örgütsel bağl1lık üzerine kavramsal inceleme. International Journal of Management and Administration, 2(3), 49-65. https://doi.org/10.29064/ijma.397853.

Şentürk, F. K., Durak, M., Yılmaz, E., Kaban, T., Kök, N. ve Baş, A. (2016). Dönüşümcü ve etkileşimci liderlik tarzlarının bireysel yenilikçiliğe etkisini belirlemeye yönelik bir araştırma. Mehmet Akif Ersoy Üniversitesi Sosyal Bilimler Enstitüsü Dergisi, 8(17), 173198. https://doi.org/10.20875/sb.31477.

Tavas, B. ve Öztürk, C. (2016). İç güvenlik hizmetlerinde çalışanların örgütsel bağl1lık ile benlik saygısı arasındaki ilişki: Türk polis teşkilatı örneklemi. International Journal of Human Sciences, 13(1), 1532-1542. https://doi.org/10.14687/ijhs.v13i1.3680.

Tuna, M., Bircan, H, ve Yeşiltaş, M. (2012). Etik liderlik ölçeği'nin geçerlilik ve güvenilirlik çalışması: Antalya Örneği. Atatürk Üniversitesi İktisadi ve İdari Bilimler Dergisi, 26(2), $143-155$.

Tuna, M. ve Yeşiltaş, M. (2013). Liderliğin etik boyutu: Etik liderliğin otel işletmelerindeki işgörenler tarafından algılanması. Iş̧letme Araştırmaları Dergisi, 5(3), 184-209.

Uğurlu, C.T., Sincar, M. ve Çınar, K. (2013). Ortaöğretim okulu öğretmenlerinin örgütsel bağl1lık düzeylerine yöneticilerinin etik liderlik davranışlarının etkisi. Erzincan Üniversitesi Eğitim Fakültesi Dergisi, 15(1), 266-281.

Ural, A. ve Kılıç, İ. (2013). Bilimsel araştırma süreci ve SPSS ile veri analizi, 4. Baskı, Ankara: Detay Yayıncilik.

Walumbwa, F., Avolio, B., Gardner, W., Wernsing, T. ve Peterson, S. (2008). Authentic leadership development and validation of a theory-based measure. Journal of Management, 34(1), 89126. https://doi.org/10.1177/0149206307308913. 
Yalçın, A. ve İplik, N. F. (2005). Beş yıldızlı otellerde çalışanların demografik özellikleri ile örgütsel bağl1lıkları arasındaki ilişkiyi belirlemeye yönelik bir araştırma: Adana İli örneği Çukurova Üniversitesi Sosyal Bilimler Enstitüsü Dergisi; 14(1), 395-412.

Yavuz, E. (2009). İşgörenlerin dönüşümcü liderlik ve örgütsel bağl1lık ile ilgili tutumlarina yönelik bir araştırma. İşletme Araştırmaları Dergisi, 1(2), 51-69.

Yavuz, E. ve Gültekin, Y. (2019). “Örgütlerde liderlik tipinin örgütsel bağlllık üzerindeki etkisi konusunda yapılmış çalışmaların meta-analizi." 4. Uluslararası Bilimsel Araştırmalar Kongresi. (Ed.) Sinem Yıldırımalp. Yalova: Doğuhan Tanıtım-Matbaa-Yayıncılık. 381-394. 